\title{
Does resource availability influence the vital rates of the tropical copepod Apocyclops royi (Lindberg, 1940) under changing salinities?
}

\author{
van Someren Gréve, Hans; Jepsen, Per Meyer; Hansen, Benni Winding
}

Published in:

Journal of Plankton Research

DOI:

10.1093/plankt/fbaa031

Publication date:

2020

\section{Document Version}

Early version, also known as pre-print

Citation for published version (APA):

van Someren Gréve, H., Jepsen, P. M., \& Hansen, B. W. (2020). Does resource availability influence the vital rates of the tropical copepod Apocyclops royi (Lindberg, 1940) under changing salinities? Journal of Plankton Research, 42(4), 467-478. https://doi.org/10.1093/plankt/fbaa031

\section{General rights}

Copyright and moral rights for the publications made accessible in the public portal are retained by the authors and/or other copyright owners and it is a condition of accessing publications that users recognise and abide by the legal requirements associated with these rights.

- Users may download and print one copy of any publication from the public portal for the purpose of private study or research.

- You may not further distribute the material or use it for any profit-making activity or commercial gain.

- You may freely distribute the URL identifying the publication in the public portal.

\section{Take down policy}

If you believe that this document breaches copyright please contact rucforsk@kb.dk providing details, and we will remove access to the work immediately and investigate your claim. 

5 18
Journal of Plankton Research

Revised manuscript version 2

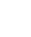

\section{Does resource availability influence the vital rates of the tropical copepod} Apocyclops royi (Lindberg, 1940) under changing salinities?

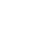

9

\section{HANS VAN SOMEREN GRÉVE, PER MEYER JEPSEN AND BENNI WINDING HANSEN*}

Department of Science and Environment, Roskilde University, Universitetsvej 1, PO Box 260, DK4000 Roskilde, Denmark

*Corresponding author: E-mail bhansen@ruc.dk

\section{(1)} 6

7 RUNNING HEAD: Vital rates of a copepod under changing salinities

KEYWORDS: Salinity tolerance; functional response; egg production; numerical response; zooplankton 


\section{ABSTRACT}

Functioning of invertebrates inhabiting coastal ecosystems is challenged by strong temporal fluctuations in salinity. We investigate how food availability influences vital rates in the tropical cyclopoid copepod Apocyclops royi under different salinities (5-32 PSU). We hypothesized that i) mortality decreases and egg production rate increases with food availability, ii) that under suboptimal salinity mortality increases and the egg production rate is reduced and iii) the threshold concentration for egg production (lowest food concentration where egg production is initiated) shifts to higher food concentrations when challenged by salinity. Surprisingly, A. royi survived, fedingested food, and produced eggs at all tested salinities. Mortality rate was however dependent on salinity level, but not on food availability. Mortality increased $\left(-12 \% \mathrm{~h}^{-1}\right)$ during short-term $(1 \mathrm{~h})$ salinity acclimatization to $5 \mathrm{PSU}$ and during the following $24 \mathrm{~h}$ incubations $\left(-5 \% \mathrm{~d}^{-1}\right)$ compared to higher salinities. Feeding- and egg production rates increased with food availability up to an optimum at all salinity levels, with no effect of salinity on the lowest food concentration initiating egg production. This reveals a high salinity tolerance by $A$. royi and may partly explain why this particular copepod is so successful compared to its congeners in occupying extreme habitats. 


\section{INTRODUCTION}

Living as a-zooplankton in near shore environments such as estuaries, lagoons or intertidal areas can be considered a challenge because of regular or rapid salinity oscillations (Mcallen et al., 1998; Rivera-ingraham and Lignot, 2017). How spatiotemporal variation in salinity affect zooplankton depends on their physiology and functioning under fluctuating salinity. Therefore salinity is a shaping environmental factor for distribution of species inhabiting these environments and the overall near shore ecosystem structure and functioning (Peterson and Ross, 1991; Henry et al., 2002; Hauton, 2016).

Dominant zooplankton in these physically rapidly changing environments are species of copepods, often below mm-sized euryhaline crustaceans. There is substantial evidence that most copepods inhabiting these environments do not strictly conform to the external salinity but have osmoregulatory capacities to various degrees. In adult species of all the dominant orders of free living copepods, Calanoida, Cyclopoida and Harpacticoida hypo- and hyperregulation of the internal osmotic pressure and ion balance (Battaglia and Bryan, 1964; Bayly, 1969; Farmer, 1980; Roddie et al., 1984; Mcallen et al., 1998) or body density (Svetlichny and Hubareva, 2014) nonisometric to the external conditions, has been observed, non-isometric to the external conditions. This indicates the process of active ion regulation.

Different from osmoconformation, osmoregulation is an energetically expensive process as iontransport is particularly ATP consuming (Hand and Hardewig, 1996; Bradly, 2009). Furthermore, elevated aerobic metabolism (mitochondrial activity) associated with exposure to salinity changes may cause oxidative stress by compromising cell functionality and it requires energy to restore the cellular redox balance (reviewed in Rivera-Ingraham and Lignot, 2017). Thus adjusting to osmotic stress infers increased energy expenditure and hence, less energy availability for other basic physiological functions of the copepod e.g. reproduction (Chen et al., 2006).

It is therefore not surprising that studies investigating the effect of salinity changes on the vital rates of copepods reveal increased respiration rates (Miliou and Moraitou-Apostolopoulou, 1991; Dutz and Christensen, 2018), decreased reproductive output and even increased mortality under suboptimal salinities (Lance, 1963; Cervetto et al., 1999; Lee et al., 2005; Chen et al., 2006; Svetlichny and Hubareva, 2014). However, the osmotic dependence of these rates, or 'salinity tolerance', varies greatly among species (Gaudy et al., 1982; Bergmans and Janssens, 1988; Lee et al., 2005). 
The constant energy requirement for osmoregulation in some copepods infers that their osmoregulatory capacity may be restricted under food-limited conditions and can be compensated when resources are available. This is supported by Rippingale and Hodgkin (1977), who showed that longevity of the calanoid copepod Sulcanus conflictus increases at hyperosmotic salinities when food was available. Similarly Hammock et al. (2016) showed that survival of the calanoid copepod Eurytemora affinis increases at hypo- or hyperosmotic salinities when resource levels are high. Further, they measured a relatively high food consumption rate at sub-optimal salinities when resources were abundant, possibly to compensate for the elevated metabolic cost due to osmoregulation. Thus, the few studies available on the effect of food presence on the copepods vital rates under hypo- or hyperosmotic salinities suggest that saturated-increased resource availability increases their tolerance to sub-optimal salinities. In the present study, we experimentally investigate if and how food availability influences the vital rates of the cyclopoid copepod Apocyclops royi at a range of salinities, expected to cover from sub-optimal to optimal salinities.

This small, euryhaline copepod inhabits tropical and sub-tropical estuaries (Muthupriya and Altaff, 2009; Su et al., 2005) and coastal saline ponds (Blanda et al., 2015; Dhanker and Whang, 2013). Salinity is an important environmental variable here, as in the coastal waters of (sub)tropical regions, which are characterized by dilution due to heavy rainfall and by evaporation dominated incidents (Muthupriya and Altaff, 2009).

A. royi is regularly exposed to abrupt and extreme salinity changes and presumably also to fluctuating food abundance due to heavy rainfall (Blanda et al., 2015). Although previous studies on $A$. royi have shown -it tolerates and reproduces over a wide range in salinity (0-35 PSU) (Muthupriya and Altaff, 2009; Pan et al., 2016), no data is available on the effect of food concentration on other vital rates of this species as a function of differences in-salinitiesy. Here we test the hypothesis that due to presumed energetic expenses for osmoregulation and oxidative stress at sub-optimal salinities vital rates are affected. Specifically we hypothesize that under sub-optimal salinities i) the mortality rate increases and maximum egg production rate areis reduced; ii) mortality decreases and egg production rate increases with food availability; and iii) that the threshold concentration for egg production (lowest food concentration where egg production is initiated) shifts to higher food concentrations when challenged by salinity. This is the first study describing the mortality, feeding and egg production responses for $A$. royi as a function of a wide span of food concentrations at different salinities. Our results are highly relevant for understanding 
98 how euryhaline copepod the vital rates of a euryhaline copepod respond to salinity changes under 99 food-limited and-or eutrophicated conditions.

100 
101

102

103

104

105

106

107

108

109

110

111

112

113

114

115

116

117

118

119

120

121

122

123

124

125

126

127

128

129

\section{METHOD}

\section{Experimental organisms}

Apocyclops royi was originally obtained from Tungkang Biotechnology Research Center, Taiwan, but was received from culturing facilities at the LOG-Marine Station of Wimereux, France (Pan et al., 2016). The copepods were kept in continuous cultures at Roskilde University (Roskilde, Denmark) at $25_{-}^{\circ} \mathrm{C}$ in $0.2 \mu \mathrm{m}$ filtered seawater (FSW) and acclimated from 20 PSU to $32 \mathrm{PSU}$ in at least 111 days ( $\sim 10$ generations). A. royi was kept in $70 \mathrm{~L}$ buckets, gently aerated and fed daily atd libitum with the marine cryptophyte algae Rhodomonas salina (strain code K-1487). R. salina was kept in culture at $18_{-}^{\circ} \mathrm{C}$ in $20 \mathrm{~L}$ plastic bags in $0.2 \mu \mathrm{m}$ FSW at $32 \mathrm{PSU}$ in exponential growth by daily dilution with FSW amended with a modified $0.1 \%$ F/2 medium deprived for cobalt chloride (Guillard, 1975; Thoisen et al., 2018). R. salina proved to have a suitable cell size ( $\sim \mu \mathrm{m}$, Table 1) for feeding all developmental stages of $A$. royi and to be sufficiently nutritious to use as sole food source for maintaining the copepod cultures. Further, $R$. salina has a high salinity tolerance, with growth rates close to $1 \mathrm{~d}^{-1}$ at salinities between 5 - 50 PSU (Jepsen et al., 2018).

\section{Experimental procedure of incubation experiments}

We determined the mortality rates, feeding rates and ovigerous rates by initiating experiments with non-egg carrying females at four salinity levels (5, 10, 20 and 32 PSU), each at 7 different food concentrations (Table 1, exp. 1-4) using bottle incubations (Frost, 1972; Kiørboe et al., 1985). Food concentrations were chosen to ensure reaching a tendency to saturation of the ingestion rate of the copepods according to other studies (e.g. Almeda et al., 2017) and trial experiments. Due to unexplainable cell degradation of $R$. salina during the incubation experiment at 10 PSU, we were not able to determine cell concentrations and feeding rates at this salinity level, thus only data on mortality rate at that particular salinity was further analyzed.

Prior to each bottle incubation experiment a mix of males and females were gently separated from the stock culture with a $200 \mu \mathrm{m}$ mesh and starved in $0.2 \mu \mathrm{m}$ FSW (32 PSU) for $19 \mathrm{~h}$ to ensure complete gut evacuation and to evoke fertilization of the females. One hour prior to the start of the

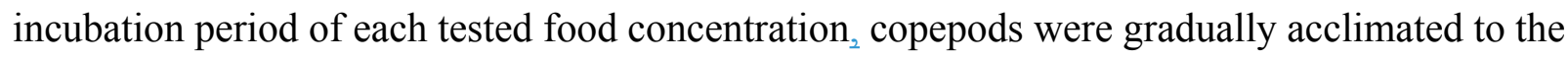
experimental salinity to avoid an acute salinity shock (Pan et al., 2016). Briefly, copepods were gradually ( $\sim-1.7 \% \mathrm{~min}^{-1}$ of final PSU) acclimated during $1 \mathrm{~h}$ from $32 \mathrm{PSU}$ to 5, 10, 20 PSU or 32 
130

131

132

133

134

PSU, respectively. To reach the desired salinity, temperature acclimated deionized water (0 PSU) was increasingly added and culture water was removed from the animals using a programmable peristaltic pump (Jebao ${ }^{\circledR}$ DP-4). Previously, dilution of seawater with deionized water havehas shown not to cause reduced physiological performances by the calanoid copepod Acartia tonsa (Jepsen et al., 2018). R. salina was acclimated to the desired experimental salinity with steps of \pm 5 PSU per day-alse by addition of deionized water, similar to like in Jepsen et al. (2018) and to the experimental temperature in $2 \mathrm{~h}$ prior to start of the experiments. Hence, there are reasons to believe that neither of our experimental organisms suffered from e.g. low calcium ion concentration.

Food suspensions were prepared by successive dilution of the highest food concentration with 0.2 $\mu \mathrm{m}$ FSW and amended with $3.5 \mathrm{~mL} \mathrm{~L}^{-1}$ modified $\mathrm{F} / 2$ algal growth medium to avoid differential growth of $R$. salina between treatments due to nutrient excretion by the copepods. For each food concentration 12 Pyrex glass bottles $(300 \mathrm{~mL})$ were filled with the suspension. Three bottles were used to measure the initial concentration, three bottles to measure algal growth during the incubation (controls) and three bottles, with copepods added, served as experimental treatments (experimental bottles). From the acclimated copepods only live, non-egg bearing females were selected under a dissection microscope and distributed over the experimental bottles (35-50 females per bottle, Table 1). The number of copepods added per bottle varied depending on food concentration, to assure an approximately $30_{-} \%$ reduction of $R$. salina at the end of the incubation. The control and experimental bottles were sealed with a screw cap and placed on a slowly rotating plankton wheel $(0.6 \mathrm{rpm})$ in dark for $24 \mathrm{~h}$ at $25^{\circ} \mathrm{C}$. At the end of the experiment, the content of each bottle was filtered through a $100 \mu \mathrm{m}$ mesh to retrieve all copepods, which were consequently checked for mortality and egg-sac production.

Food concentrations (cells $\mathrm{mL}^{-1}$ ) of the initial, control and experimental bottles were determined using a Beckman Coulter Multisizer 4e. The salinity of the food suspension was measured at the start of each experiment with an Atago S/Mill-E hand-held refractometer with a resolution of 0.5 units. Prosome length (Table 1$)$ of live copepods $\left(\mathrm{n}_{-}=25\right.$, immobilized by cooling) were measured at termination of each experiment from digital images taken with a Nikon SMZ 18 stereomicroscope mounted with a Nikon DS-Fi2 camera, using the imaging processing software NIS-Elements-Imaging Software.

\section{Experimental procedure of short-term salinity acclimatization experiment}


160 To investigate copepod resilience to the short-term salinity acclimatization prior to the start of the 161 previous described incubation experiments, we conducted an additional experiment (Table 1, exp. 162 5) where we determined copepod mortality after a $1 \mathrm{~h}$ acclimatization period. Briefly, a mix of 163 males and females were separated from the stock culture with a $200 \mu \mathrm{m}$ mesh and starved in $0.2 \mu \mathrm{m}$ 164 FSW (32 PSU) for $19 \mathrm{~h}$. Prior to the salinity acclimatization three replicates of 50 non-egg carrying 165 females were prepared per treatment. The procedure for salinity acclimatization was similar as 166 described previously for experiment 1-4. Copepod mortality (copepods were considered dead when 167 a response to mechanical stimuli was absent) was determined 30 minutes after the acclimatization 168 period with a dissection microscope.

\section{Mortality rate}

Mortality rate $\left(\mathrm{M}, \% \mathrm{t}^{-1}\right)$ of $A$. royi after short-term salinity acclimatization and after the $24 \mathrm{~h}$ incubation experiments was calculated as

$$
M=\frac{\text { nalive }_{\text {start }}-\text { nalive }_{\text {end }}}{\text { nalive }_{\text {start }} * 0.01} * t^{-1}
$$

, where $t$ is the incubation period in hours or days.

\section{Functional feeding response}

The ingestion rate, clearance rate and average food concentration during the incubation experiments were calculated according to Frost (1972). The sigmoidal shape of the observed feeding response suggested the presence of a feeding threshold, below which the copepod reduces its feeding rate. Therefore, a Holling type III functional response model was fitted to the measured ingestion and clearance rates (Table 2). This is similar to Schultz and Kiørboe (2009) and van Someren Gréve et al. (2017), where model parameter $\beta$ is the maximum clearance rate $\left(\mathrm{mL} \mathrm{d}^{-1}\right), \mathrm{C}$ is the prey concentration (cells $\mathrm{mL}^{-1}$ ) and $\alpha$ is the prey concentration at the maximum clearance rate. The maximum ingestion rate, $I_{\max }$, was calculated as $\alpha \beta \mathrm{e}^{1}\left(\right.$ cells $\left.\operatorname{cop}^{-1} \mathrm{~d}^{-1}\right)$.

Carbon content of the prey item ( $R$. salina) was determined by CHN elemental analysis. Briefly, triplicates of ca. $10^{7}$ cells were filtered onto $12 \mathrm{~mm}$ diameter pre-combusted GF/C filters (Whatman), dried at $60_{-}^{\circ}-\mathrm{C}$ for $24 \mathrm{~h}$ and analyzed by a Thermo Fisher Scientific FLASH 2000 
186

187

188

189

190

191

192

Organic Elemental Analyzer. A methionine standard curve was used to obtain concentrations of C and $\mathrm{N}$.

\section{Ovigerous rate}

Directly after termination of each feeding experiment, the presence of egg sacs was determined under a dissection microscope. Similar to Rayner et al. (2017) we calculated the female ovigerous rate $\left(G, \%\right.$ of ovigerous females $\left.\mathrm{d}^{-1}\right)$ for each replicate by

$$
G=\frac{\text { ovigerous copepods }_{\text {end }}}{\text { copepods alive }_{\text {end_____. }} 0.1} * t^{-1}
$$

The dependence of the ovigerous rate on the food concentration was described by thea model similar to Kiørboe et al. (1982) (see Table 2), where $G_{\max }$ equals the maximum ovigerous rate (\% of ovigerous females $\mathrm{d}^{-1}$ ), $C$ the food concentration (cells $\mathrm{mL}^{-1}$ ) and $b$ a constant.

\section{Gross efficiency of egg production}

The gross efficiency of egg production was calculated from the functional response and ovigerous rate observations according to Peterson (1988):

$$
E=\frac{C_{\text {eggs }} \operatorname{cop}^{-1} d^{-1}}{C_{\text {ingested }} \operatorname{cop}^{-1} d^{-1}}
$$

, where egg carbon produced per copepod $\left(\mu \mathrm{g} \mathrm{C} \operatorname{cop}^{-1} \mathrm{~d}^{-1}\right)$ was calculated by multiplying the measured average clutch size (n eggs $\left.\operatorname{cop}^{-1}\right)$ by the ovigerous rate $\mathrm{G}(\%)$ and egg carbon content $(\mu \mathrm{g}$ $\left.\mathrm{C} \mathrm{egg}^{-1}\right)$. The egg carbon content was calculated from measured egg diameter $\left(\mathrm{n}_{-}=20\right.$ per experiment) and the egg diameter to carbon equation for copepods derived by Uye and Sano (1995).

Further, the maximum weight-specific fecundity ( $\mu \mathrm{g} \mathrm{C}_{\text {eggs }} \mu \mathrm{g} \mathrm{C}_{\text {copepod }}{ }^{-1} \mathrm{~d}^{-1}$ ) was calculated from the maximum total egg carbon produced per copepod and measured copepod sizes $\left(\mathrm{n}_{-}=25\right.$ per experiment, Table 1), using the length-dry weight relationship for A. royi by Chang and Lei (1993) and dry weight-carbon relationship for copepods according to Kiørboe and Sabatini (1995).

\section{Statistics}


209 We conducted an analysis of variance (ANOVA and Tukey post-hoc test) to determine the 210 significance level $\left(\mathrm{p}_{-}<0.05\right)$ of differences in mortality between salinity levels using the software 211 SPSS Statistics 20. All models (Table 2) were fitted to the observational data using the software 212 Sigmaplot 14.0. To compare differences in the vital rates (ingestion rate, clearance rate, maximum 213 ovigerous rate, gross efficiency of egg production) between salinities for non-linear models fitted to 214 the experimental data, we calculated the Wald confidence intervals (95_\%) for each model 215 parameter. 
217

218

219

220

221

222

223

224

225

226

227

\section{RESULTS}

The $M$ mortality rate of $A$. royi during short-term $(1 \mathrm{~h})$ salinity acclimatization after a $19 \mathrm{~h}$ starvation period was highest at 5 PSU (12.6 $\pm 2.1 \%$ mortality $\left.\mathrm{h}^{-1}\right)$ compared to 10, 20 and 32 PSU (4.6 \pm 1.4 , 3.6 $\pm 0.7,3.7 \pm 0.5 \%$ mortality $\mathrm{h}^{-1}$ respectively, Fig 1$)$. During the following $24 \mathrm{~h}$ incubation, with or without food, the average mortality showed a similar salinity dependent trend, with highest measured mortality rates at $5 \mathrm{PSU}\left(6.8 \pm 0.9 \%\right.$ mortality $\left.^{-1}\right)$ and lowest mortality at $32 \mathrm{PSU}$ ( $1.8 \pm 0.4 \%$ mortality $\mathrm{d}^{-1}$, Fig $\left.2 \mathrm{~d}\right)$. Both during the short-term $(1 \mathrm{~h})$ acclimatization and following incubation a significantly higher mortality was observed at PSU 5 compared to 10, 20 and 32 PSU $\left(\mathrm{p}_{-}<0.05\right)$. No significant differences in mortality were observed between 10, 20 and 32 PSU though. Food availability did not appear to influence the mortality of $A$. royi during the incubations (Fig 2a-c).

The cumulative mortality of $A$. royi during the experiment (mortality during $1 \mathrm{~h}$ salinity acclimatization $+24 \mathrm{~h}$ incubation with/without food) was consequently highest and statistically significantly different at 5 PSU $\left(19.4 \pm 2.3 \%, \mathrm{p}_{-}<0.05\right)$ and lowest at $32 \mathrm{PSU}$, with no significant differences in mortality between 10,20 and 32 PSU $(8.4 \pm 1.7,5.7 \pm 0.8,5.5 \pm 0.6 \%$ respectively, Fig 3).

The feeding rate of $A$. royi varied depending on food concentration at all tested salinities (Fig 4a-c, e-f). The ingestion rate increased with food concentration towards saturation. The estimated maximum ingestion rates $\left(I_{\max }\right)$ did not differ (overlapping 95\% CL) between the tested salinities (44.459 $\pm 9.157,36.377 \pm 21.627$ and $48.783 \pm 10.939$ cells cop ${ }^{-1} \mathrm{~d}^{-1}$ at 5, 20 and 32 PSU respectively, Fig 4d). The observed clearance rate was very low at the lowest tested food concentrations and increased with food concentration up to an optimum ( $\beta$, Table 2$)$ followed by a decrease with increasing food availability, indicating $A$. royi exhibited a typical Holling type III functional feeding response (Fig 4e-g). The estimated maximum clearance rate did not differ ( $95 \%$ confidence intervals overlap) between salinities, (Fig 4h). Model parameters of the fitted functional response model to the observations are shown in Table 2.

The ovigerous rate of $A$. royi ( $\%$ of ovigerous females $\mathrm{d}^{-1}$ ) varied with food concentration in a similar fashion as the observed feeding rate (Fig 5a-c). Generally, the percentage of egg carrying females increased with increasing food availability towards a maximum. No differences in maximum ovigerous rates were observed between salinities (61.5-61.9\%, Fig 5a-c), neither in the 
estimated maximum ovigerous rates (Fig $5 \mathrm{~d}$, Table 2). The observed maximum weight-specific fecundity was equal to $0.176 \mu \mathrm{g} \mathrm{C}_{\text {eggs }} \mu \mathrm{g} \mathrm{C}_{\text {copepod }}{ }^{-1} \mathrm{~d}^{-1}$, regardless the treatment.

249 Egg production was completely absent when no food was present, but was initiated at all tested 250 salinities at the lowest food concentrations offered (Fig 5a-c). Contrary to the ovigerous rate, the 251 clutch size was largely independent of food availability (Fig 5h) and only decreased at the lower 252 end of the tested concentrations. There did not appear to be a correlation between food 253 concentration and the gross efficiency of egg production (Fig 5e-f). However, egg production was 254 positively correlated to ingestion rate (Fig 6), showing a gross efficiency of egg production of $A$. 255 royi ranging between 10-12\%, with no significant differences between salinities (parameter $a$, 256 Table 2). Model parameters of the fitted models to the observations for ovigerous rate, clutch size 257 and gross efficiency of egg production are shown in Table 2.

258 Overall, our observations suggest that during and after a short-term acclimatization ( $1 \mathrm{~h})$ to low 259 saline water, mortality of $A$. royi increased compared to when exposureed to 32 PSU. However, 260 short-term acclimatization did not compromise the ability to feed and produce eggs within the 261 following $24 \mathrm{~h}$ incubations. Further, food availability did not influence the mortality rate, but 262 strongly influences $\underline{d}$ feeding rate and egg production in a sigmoidal fashion. 


\section{DISCUSSION}

265

266

The physiological cost of regulating body osmolarity and ion balance in coastal copepods has been investigated and quantified extensively during the past decades. This has been conducted by monitoring end-points at different levels e.g. in terms of mortality, growth rate, reproduction rate and metabolic rate. These studies indicate that increased energy allocation due to osmoregulation significantly compromise energy investment in growth and reproduction and the overall viability of embryonic, naupliar; and adult life stages (e.g. Devreker et al., 2007; Dutz and Christensen, 2018). However., The presence of an adequate food source may, in part, cover the increased energetic needs imposed by osmoregulation and thereby dampen the negative physiological response by copepods (Rippingale and Hodgkin, 1977), but.-However, multiple stressor experiments on salinity tolerance, taking into account the effect of resource availability are rare, particularly for copepods. This is surprising as estuarine species often reside in environments with strong temporal variations in both abiotic and biotic factors (Devassy and Goes, 1988; Madhu et al., 2007; Martinez et al., 2011). In the present study, we investigated the physiological response to different salinities of the small, tropical copepod $A$. royi exposed to different food concentrations. A. royi exhibit a relatively short generation time of approximately $10 \mathrm{~d}$ under the present cultivation conditions with food in excess. We showed that salinity affects the mortality rate of $A$. royi, during short term $(1 \mathrm{~h})$ salinity acclimatization and a following $24 \mathrm{~h}$ incubation period, but not the ovigerous rate. Moreover, food availability did not influence the osmotic dependence of mortality, feeding rate or ovigerous rate of this species.

\section{The effect of salinity and food availability on mortality}

Acclimatization or plasticity and adaption to different abiotic factors in marine copepods are poorly understood (Lee and Petersen, 2003). It varies greatly between species (Calliari et al., 2008) and within species and may depend on acclimatization period and biotic factors, such as food availability (Dutz and Christensen, 2018; Lindley et al., 2011). We observed the highest mortality of $A$. royi directly after each short-term salinity acclimatisation (Fig. 1) and somewhat lower mortality during the following $24 \mathrm{~h}$ incubation, regardless the absense or presence of food (Fig. 2ad). Overall, mortality of $A$. royi in our study was highest when exposed to the lowest tested salinity (5 PSU, Fig 1, 2d and 3) as hypothesized. In our experiments, we acclimatized A. royi by changing from 32 PSU during $1 \mathrm{~h}$ to either 20, 10 or 5 PSU. We used a similar acclimation method as 
described in Pan et al. (2016). As a result, Pan et al. (2016) found a sigmoidal survival curve as a function of salinities ranging from 0 to 35 PSU, with an optimum of 20 PSU. Muthupriya and Altaff (2009) however, showed a mortality of $A$. royi lowest at 12 PSU and highest at 32 PSU. In the present study, we observed an elevated mortality after acclimatization in 5 PSU but did not see any difference between 10 and 32 PSU (Fig 1 and 2). We consider this is an effect of that our $A$. royi strain has been reared at 32 PSU for several generations and therefore may have adapted to this condition, but still has kept the ability to perform well at 20 PSU. This suggests that within species, salinity tolerance is population specific or even may be related to pre-experimental rearing conditions.

\section{Excess fFood availably has previously shown to reduce mortality of copepods exposed to} hypersaline environments (Rippingale and Hodgkin, 1977; Hammock et al. 2016). This elevated salinity tolerance is supported by Aa study by Lindley et al. (2011) on the species Apocyclops panamensis, a close relative to $A$. royi $i_{3 .}$ They investigated the effect of short-term $(3 \mathrm{~h})$ acclimatization to a hypersaline environment, from 6.6 PSU to 30 PSU_(Lindley et al., 2011). Theyand showed a significant increase of the intracellular free amino acid (FAA) pool in the animals and an even higher increase when the copepods were offered additional FAAs (Lindley et al., 2011). FAAs, such as proline, alanine, glycine and taurine have been shown to be major osmolytes in marine invertebrates (Helland et al., 2000). Their observed built up of FAAs in $A$. panamensis could be dedicated to protein catabolism, but increase of intracellular FAAs also depends on food intake (amino acids) presumably accounting for their observed larger FAA pool when the copepods were enriched with FAAs (Farmer and Reeve, 1978). The effect of food availability on mortality of copepods in hypersaline environments has been demonstrated by Hammock et al. (2016), who observed increased mortality of the euryhaline copepod Eurytemora affinis with increasing salinity at low food availability, compared to high food availability.

Contrary to our hypothesis, food availability did not influence the osmotic dependence of mortality of $A$. royi (Fig 2a-c). This may be partly explained by the fact that fin our study-on the other hand, the copepods were exposed to hyposaline environments. Adjusting the internal osmolarity to a lowered external salinity requires down-regulation of the intracellular FAA pool (Farmer and Reeve, 1978). Protein synthesis and enhanced excretion account for the decrease of the FAA pool and this mechanism is even active in the absence of food (Farmer and Reeve, 1978). This may partly explain, contrary to our hypothesis, the absence of an effect of food availability on mortality 


\begin{abstract}
325 of $A$. royi in response to lower salinity (Fig $2 a-c$ ). In order to To understand the underlying mechanism of osmoregulation in $A$. royi-, it would therefore be interesting to investigate in future studies changes in FAA concentrations in $A$. royi as an effect of decreasing external salinity and functional feeding response.
\end{abstract}

Another possible explanation of the absence of an effect of food availability on mortality could be a decrease in energetic expenses related to foraging activity at low food concentrations, allowing energy allocation to energy demanding osmoregulatory processes, such as ion transport (Hand and Hardewig, 1996; Bradly, 2009) and restoring the cellular redox balance (reviewed in RiveraIngraham and Lignot, 2017). The observed functional response of $A$. royi follows a Holling type III response (Fig 4) suggesting that feeding activity ceases when food availability is limited. Optimal foraging theory predict such a response for actively foraging zooplankton (Kiørboe et al., 2018) in order to reduce the energetic cost for searching for food at low food conditions. In fact, for various marine copepod species such a behavioral response has been observed, which can be dedicated to reduced swimming activity at low food concentrations (Kiørboe, 2016). However, no direct observational studies exist on $A$. royi foraging tactics and the effect of food availability on foraging behavior verifying such a behavioral response.

\title{
The effect of salinity and food availability on feeding rate
}

The effect of salinity on the feeding rate of copepods has been scarcely studied. Feeding rate may be increased under iso-osmotic conditions in order teto compensate for the increased metabolic demand imposed by osmoregulation (Gaudy et al. 2000). On the other hand, exposure to extreme iso-osmotic conditions may reduce the predatory capabilities of an animal, thereby reducing the animals' feeding rate_(Hammock et al., 2016; Rivera-Ingraham and Lignot, 2017).

Calliari et al. (2008) investigated the effect of instantaneous salinity reduction on the feeding rate of A. tonsa and A. clausi and showed a substantial decrease in both ingestion rate and clearance rate of both species when salinity was lowered from 32 PSU to 14 and 4 PSU, respectively. Their results indicate that sudden lowering of salinity significantly decreases the feeding rate by these species and thereby potentially influence the plankton dynamics in the coastal system these species reside. The euryhaline species Eurytemora affinis on the other hand, showed an opposing response and considerably increased its consumption rate when exposed to increased salinity. However, when 
exposed to increased salinity under low food levels, E. affinis did not increase its feeding rate and their growth was reduced (Hammock et al., 2016).

We did not observe a significant decrease or increase in either ingestion or clearance rate with decreasing salinity (Fig 4), which may be together with the relatively low observed mortality rates an indicator for the overall high salinity tolerance of $A$. royi exposed to lower salinities. In comparison, the mortality rates observed for $A$. tonsa and $A$. clausi which lowered their feeding rate in hyposaline environments (Calliari et al., 2008) were much higher (31.3 and $20 \%$, respectively) than observed for A. royi (from 1.8 to $6.8 \%$ ) (Fig 1 and 2).

A possible reason for the absence of increased feeding rates in A. royi exposed to hyposaline conditions could be differences in osmotic regulation mechanisms, where. Ddown-regulation of the FAA $\underline{s}$ may be independent of feeding, contrary to up-regulation (synthesis) of FAA $\underline{s}$ as in $E$. affinis exposed to hypersaline environments, which requires food uptake (Farmer and Reeve, 1978; Hammock et al., 2016).

\section{The effect of salinity and food availability on egg production}

Exposure to hypo or hypersaline environments may reduce egg production rates in copepods due to increased energy allocation to osmoregulation (Gaudy et al., 2000). It is therefore not surprising that reduced egg production rates have been observed in various species when subjected to hyposaline environments (Dutz and Christensen, 2018; Calliari et al., 2006)..In the present study, we investigated the ovigerous rate of $A$. royi at different salinities over a gradient in food availability. Whereas the food availability dependent egg production of $A$. royi has not been previously described, s_Salinity dependent egg production has been scarcely studied in a few cases for this-Apocyclops royispecies. Muthupriya and Altaff (2009) and Pan et al. (2016) tested the longterm egg production rate of aclimated $A$. royi in the presence of food and showed, similar to our observations (Fig 5), that $A$. royi is capable of maintaining egg production at a wide range of salinities (0-35 PSU) with optimal conditions varying between 12-20 PSU. Salinity above 35 PSU appeared to be unfavorable in terms of egg production (Muthupriya and Altaff, 2009). Hatching success and postembryonic development as maxima for nauplii production were observed between 10-20 PSU (Lee et al., 2005; Pan et al., 2016) and maximum culture densities were reached at 20 PSU (Pan et al., 2016). In the present study the maximum ovigerous rate of $A$. royi was not significantly affected by salinity (Fig 5d), contrary to our hypothesis. 
Further, we did not observe an affect of salinity on the threshold concentration for egg production, thus rejecting our hypothesis that the threshold concentration for egg production would shifts to $\underline{\text { higher food concentrations when exposed to sub-optimal salinities. Egg production was, regardless }}$ $\underline{\text { salinity treatment, initiated at the lowest food concentrations offered (Fig 5a-c) and showed, as }}$ hypothesized a food density dependency in reproductive output principally similar to its congeners (e.g. Berggreen et al., 1988; Sabatini and Kiørboe, 1994). The maximum weight-specific fecundity of $A$. royi measured here also did not vary between salinities $\left(0.18 \pm 0.0 \mu \mathrm{g} \mathrm{C}_{\text {eggs }} \mu \mathrm{g}^{-1} \mathrm{C}_{\text {copepod }} \mathrm{d}^{-1}\right)$ and is relatively high compared to similar sized egg sac carrying copepods, but low compared to broadcast spawners (Kiørboe and Sabatini, 1995).

Gaudy et al. (1982) observed a similar absence of response in egg production over a wide range in salinity. They did not observe variation in ovigerous rate of the exceptionally euryhaline harpacticoid copepod species Tisbe holothuriae. However, the majority of copepod species tolerate a much narrower salinity range before egg production is reduced (e.g. Hall and Burns, 2002; Holste and Peck, 2006; Dutz and Christensen, 2018). We did not measure egg hatching success or larval development to assess the salinty effect on the full life-cycle and population dynamics of $A$. royi. From the few studies that exist these are more salinity dependent than egg production and may vary greatly depending on the copepod strain used (Lee et al., 2005; Pan et al., 2016).

\section{Ecological implications Success of $A$. rovi in an extreme habitat}

The Apocyclops royi strain used in the present study was isolated from artificial aquaculture ponds in Taiwan. These ponds we consider representing an extreme habitat. Each of the ponds cover an area $\sim 0.7$ ha and is $1 \mathrm{~m}$ deepha, is $1 \mathrm{~m}$ deep, and filled with coastal water from the nearby South China Sea. Hence, it is reasonable to assume that the copepods are not native to these ponds, but originate from the South China Sea (Blanda et al., 2015). Brackish water systems generally show strong temporal fluctuations in environmental conditions, and the ponds $A$. royi is isolated from are documented to fluctuate in biotic and abiotic conditions on a seasonal and even daily basis (Blanda et al., 2015, 2017). For example, oxygen levels in these ponds reach hypoxic conditions on a daily basis and severe hypoxia on a weekly basis, with $A$. royi still thriving in these ponds (Blanda et al., 2015). Salinity is variable over the season, but more interestingly, short-term drops in salinity of 6 PSU are observed due to heavy monsoon rain events. Hence, A. royi is exposed to abrupt salinity changes in its natural environment and is able tecan successfully maintain its population. This 
correlates well with our results where decreasing salinities resulted in only minor increase in mortality rates and no effect on ovigerous rate (Fig 1, 2 and 5). Moreover, A. royi is able to upgrade their fatty acid pool to become richer in long chained fatty acids (Rayner et al., 2017; Nielsen et al., 2019). These traits, combined with a low osmotic dependency of the vital rates of $A$. royi as shown in the present study, most likely contribute to the fact that $A$. royi can survive and is one of the predominant copepod species in Taiwanese aquaculture ponds (Blanda et al., 2015; Rayner et al., 2015).

\section{Salinity tolerance of $A$. royi}

Here we tested the hypothesis that due to presumed energetic expenses for osmoregulation and oxidative stress at sub-optimal salinities vital rates of $A$. royi are affected. Firstly, we hypothesized that under sub optimal salinities the mortality rate increases, and maximum egg production rate are reduced. This hypothesis was partly rejected as mortality rate increased when exposed to a lowered salinity during salinity acclimatization and incubation period (Fig 1, 2 and 3), but egg production was not reduced (Fig 5).

Second, we hypothesized that mortality decreases, and egg production rate increases with food availability. Egg production increased with increasing food availability (Fig 4) as expected from previous research on food dependency of egg production. However, we did not observe a decrease in mortality rate with increasing food availability (Fig 2).

Lastly, we hypothesized that the threshold concentration for egg production (lowest food concentration where egg production is initiated) shifts to higher food concentrations when challenged by salinity. This hypothesis was rejected as at all tested salinities egg production was absent when no food was present, but was initiated at the lowest food concentrations offered (Fig $5 a-c)$.

\section{CONCLUSIONS}

In the present study we experimentally investigated the physiological response of the tropical copepod Apocyclops royi to different salinities under varying food availability. We showed that the tropical copepod $A$.pocyclops royi is a euryhaline species. Its mortality rate increased during and after short-term (1 h) acclimatization to low salinity (5 PSU), whereas the individual feeding- and 
442 ovigerous rate was not affected at all during our $24 \mathrm{~h}$ exposure experiments. Food availability 443 directly influenced the ovigerous rate and feeding rate of $A$. royi in a sigmoidal manner, but did not 444 influence the threshold concentration for egg production or the mortality rate of this species when 445 exposed to sub-optimal salinities.

\section{ACKNOWLEDGEMENTS}

447 We would like to thank M.Sc. Bolette Lykke Holm Nielsen and technicians Katja Lynnerup Hansen 448 and Anne Busk Faarborg for their help during the experimental procedure. We would also like to 449 thank the reviewers for constructive critique to an earlier version of our manuscript.

\section{FUNDING}

451 This work was supported by a Villum Foundation project no. 8960 Acartia tonsa Molecular 452 PHysiology - Implementation of novel and fast tools to assess COPepod physiological states 453 (AMPHICOP) to B.W.H.

\section{DATA ARCHIVING}

455 No supplementary data related to this article is archived. 
456

457

458

459

460

461

462

463

464

465

466

467

468

469

470

471

472

473

474

475

476

477

478

479

480

481

\section{REFERENCES}

Almeda, R., van Someren Gréve, H. and Kiørboe, T. (2018) Prey perception mechanism determines maximum clearance rates of planktonic copepods. Limnol. Oceanogr., 63, 2695-2707.

Battaglia, B. and Bryan, G. (1964) Some aspects of ionic and osmotic regulation in Tisbe

(Copepoda, Harpacticoida) in relation to polymorphism and geographical distribution. J. Mar. Biol. Assoc. U. K, 44, 17-31.

Bayly, I. A. E. (1969) The body fluids of some centropagid copepods: Total concentration and amounts of sodium and magnesium. Comp. Biochem. Physiol., 28, 1403-1409.

Berggreen, U., Hansen, B. and Kiørboe, T. (1988) Food size spectra, ingestion and growth of the copepod Acartia tonsa during development: implications for determination of copepod production. Mar. Biol., 99, 341-352.

Bergmans, M. and Janssens, P. P. M. (1988) Competition between the sibling species Tisbe holothuriae and T. battagliai (Harpacticoida). Hydrobiologia, 167, 455-462.

Blanda, E., Drillet, G., Huang, C.-C., Hwang, J.-S., Jakobsen, H. H., Rayner, T. A., Su, H.-M., Wu, C.-H. and Hansen, B.W. (2015) Trophic interactions and productivity of copepods as live feed from tropical Taiwanese outdoor aquaculture ponds. Aquaculture, 445, 11-21.

Blanda, E., Drillet, E., Huang, C.-C., Hwang, J.-S., Højgaard, J. K., Jakobsen, H. H., Rayner, T. A., Su, H.-M. and Hansen, B. W. (2017) An analysis of how to improve production of copepods as live feed from tropical Taiwanese outdoor aquaculture ponds. Aquaculture, 479, 432-441.

Bradly, T. (2009) Animal Osmoregulation (Oxford Animal Biology Series). Oxford University Press, New York. 184 pp. ISBN 13: 978-0198569961.

Calliari, D., Andersen, C. M., Thor, P., Gorokhova, E. and Tiselius, P. (2006) Salinity modulates the energy balance and reproductive success of co-occurring copepods Acartia tonsa and A. clausi in different ways. Mar. Ecol. Prog. Ser., 312, 177-188.

Calliari, D., Andersen B. M. C., Thor, P., Gorokhova, E. and Tiselius, P. (2008) Instantaneous salinity reductions affect the survival and feeding rates of the co-occurring copepods Acartia tonsa 
482

483

484

485

486

487

488

489

490

491

492

493

494

495

496

497

498

499

500

501

502

503

504

505

Dana and A. clausi Giesbrecht differently. J. Exp. Mar. Biol. Ecol., 362, 18-25.

Cervetto, G., Gaudy, R. and Pagano, M. (1999) Influence of salinity on the distribution of Acartia tonsa (Copepoda, Calanoida). J. Exp. Mar. Biol. Ecol., 239, 33-45.

Chang, W.-B. and Lei, C.-H. (1993) Development and energy content of a brackish-water copepod, Apocyclops royi (Lindberg) reared in a laboratory. Bull. Inst. Zool., Academia Sinica, 32, 62-81.

Chen, Q., Sheng, J., Lin, Q., Gao, Y. and Lv, J. (2006) Effect of salinity on reproduction and survival of the copepod Pseudodiaptomus annandalei Sewell, 1919. Aquaculture, 258, 575-582.

Devassy, V. P. and Goes, J. I. (1988) Phytoplankton community structure and succession in a tropical estuarine complex (central west coast of India). Estuar. Coast. Shelf Sci., 27, 671-685.

Devreker, D., Souissi, S., Forget-Leray, J. and Leboulenger, F. (2007) Effects of salinity and temperature on the post-embryonic development of Eurytemora affinis (Copepoda; Calanoida) from the Seine estuary: a laboratory study. J. Exp. Mar. Biol. Ecol., 368, 113-123.

Dhanker R. and Whang, J.-S. (2013) Predation by Apocyclops royi (Cyclopoid: Copepod) on ciliates and rotifers. J. Mar. Sci. Technol., 21, 246-251.

Dutz, J. and Christensen, A. M. (2018) Broad plasticity in the salinity tolerance of a marine copepod species, Acartia longiremis, in the Baltic Sea. J. Plankton. Res., 40, 342-355.

Farmer, L. (1980) Evidence for hyporegulation in the calanoid copepod, Acartia tonsa. Comp. Biochem. Physiol., 65A, 359-362.

Farmer, L. and Reeve, M.R. (1978) Role of the free amino acid pool of the copepod Acartia tonsa in adjustment to salinity change. Mar. Biol., 48, 311-316.

Frost, B. W. (1972) Effects of size and concentration of food particles on the feeding behavior of the marine planktonic copepod Calanus pacificus. Limnol. Oceanogr., 17, 805-815.

Gaudy, R. and Guerin, J. P. (1982) Population dynamics of Tisbe holothuriae (Copepoda; Harpacticoida) in exploited mass cultures. Neth. J. Sea Res., 16, 208-216. 
506 Gaudy, R., Cervetto, G. and Pagano, M. (2000) Comparison of the metabolism of Acartia clausi and A. tonsa: influence of temperature and salinity. J. Exp. Mar. Biol. Ecol., 247, 51-65.

508 509 510 511 512 513

Guillard, R. R. L. (1975) Culture of phytoplankton for feeding marine invertebrates. In Culture of marine invertebrate animals (ed. Smith, W. L and Chanley, H. M.), pp 26-60. Springer, Boston, MA. ISBN 978-1-4615-8714-9.

Hall, C. J. and Burns, C. W. (2002) Effects of temperature and salinity on the survival and egg production of Gladioferens pectinatus Brady (Copepoda: Calanoida). Estuar. Coast. Shelf Sci., 55, $557-564$.

Hammock, B. G., Lesmeister, S., Flores, I., Bradburd, G. S. and Hammock, F. H. (2016) Low food availability narrows the tolerance of the copepod Eurytemora affinis to salinity, but not to temperature. Estuaries Coast., 39, 189-200.

Hand, S. C. and Hardewig, I. (1996) Downregulation of cellular metabolism during environmental stress: Mechanisms and implications. Annu. Rev. Physiol., 58, 539-63.

Hauton, C. (2016) Effects of salinity as a stressor to aquatic invertebrates. In Stressors in the Marine Environment. Physiological and ecological responses; societal implications (ed. Solan, M. and Whitley, N. M.), pp. 3-24. Oxford University Press, Oxford, United Kingdom. ISBN: 978-0-19871882-6.

Helland, S., Triantaphyllidis, G. V., Fyhn, H. J., Evjen, M. S., Lavens, P. and Sorgeloos, P. (2000) Modulation of the free amino acid pool and protein content in populations of the brine shrimp Artemia spp. Mar. Biol., 137, 1005-1016.

Henry, R. P., Garrelts, E. E., McCarty, M. M. and Twole, D. W. (2002) Differential induction of branchial carbonic anhydrase and $\mathrm{Na}+/ \mathrm{K}+$ ATPase activity in the euryhaline crab, Carcinus maenas, in response to low salinity exposure. J. Exp. Zool., 292, 595-603.

Holste, L. and Peck, M. A. (2006) The effects of temperature and salinity on egg production and hatching success of Baltic Acartia tonsa (Copepoda: Calanoida): a laboratory investigation. Mar. Biol., 148, 1061-1070.

Jepsen, P. M., Thoisen, C. V., Carron-Cabaret, T., Pinyol-Gallemí, A., Nielsen, S. L. and Hansen, B. W. (2018) Effects of salinity, commercial salts, and water type on cultivation of the cryptophyte microalgae Rhodomonas salina and the calanoid copepod Acartia tonsa. J. World Aquacult. Soc., 
535

536

537

538

539

540

541

542

543

544

545

546

547

548

549

550

551

552

553

554

555

556

557

50, 104-118.

Kiørboe, T. (2016) Foraging mode and prey size spectra of suspension-feeding copepods and other zooplankton. Mar. Ecol. Prog. Ser., 558, 15-20.

Kiørboe, T., Møhlenberg, F. and Hamburger, K. (1985) Bioenergetics of the planktonic copepod Acartia tonsa: relation between feeding, egg production and respiration, and composition of specific dynamic action. Mar. Ecol. Prog. Ser., 26, 85-97.

Kiørboe, T., Møhlenberg, F. and Nicolajsen, H. (1982) Ingestion rate and gut clearance in the planktonic copepod Centropages hamatus (Lilljeborg) in relation to food concentration and temperature. Ophelia, 21, 181-194.

Kiørboe, T. and Sabatini, M. (1995) Scaling of fecundity, growth and development in marine planktonic copepods. Mar. Ecol. Prog. Ser., 120, 285-298.

Kiørboe T., Saiz E., Tiselius P. and Andersen K. H. (2018) Adaptive feeding behavior and functional responses in zooplankton. Limnol. Oceanogr., 63, 308-321.

Lance, J. (1963) The salinity tolerance of some estuarine planktonic copepods. Limnol. Oceanogr., 8, 440-449.

Lee, K.-W., Kwon, O.-N. and Park, H.-G. (2005) Effects of temperature, salinity and diet on the productivity of the cyclopoid copepod, Apocyclops royi. J. of Aquaculture, 18, 52-59.

Lee, C. E., and Petersen, C. H. (2003) Effects of developmental acclimation on adult salinity tolerance in the freshwater-invading copepod Eurytemora affinis. Physiol. Biochem. Zool., 76, 296301.

Lindley, L. C., Phelps, R. P., Davis, D. A. and Cummins, K. A. (2011) Salinity acclimation and free amino acid enrichment of copepod nauplii for first-feeding of larval marine fish. Aquaculture, $\mathbf{3 1 8}$, 402-406.

Madhu, N. V., Jyothibabu, R., Balachandran, K. K., Honey, U. K., Martin, G. D., Vijay, J. G., Shiyas, C. A., Gupta, G. V. M. and Achuthankutty, C. T. (2007) Monsoonal impact on planktonic standing stock and abundance in a tropical estuary (Cochin backwaters - India). Estuar. Coast. Shelf Sci., 73, 54-64. 
Martinez, E., Antoine, D., D’ Ortenzio, F. and de Boyer Montégut, C. (2011) Phytoplankton spring and fall blooms in the North Atlantic in the 1980s and 2000s. J. Geophys. Res., 116, C11029.

Mcallen, R. J., Taylor, A. C. and Davenport, J. (1998) Osmotic and body density response in the harpacticoid copepod Tigriopus brevicornis in supralittoral rock pools. J. Mar. Biol. Ass. U.K., 78, 1143-1153.

Miliou, H. and Moraitou-Apostolopoulou, M. (1991) Variations of respiratory rate of Tisbe holothuriae Humes (copepoda, harpacticoida) in relation to temperature, salinity and food type. Comp. Biochem. Physiol., Part A: Physiology, 100, 169-174.

Muthupriya, P. and Altaff, K. (2009) Effect of salinity and temperature on the reproduction of the estuarine copepod Apocyclops royi (Lindberg, 1940). J. Exp. Zoology India, 12, 103-106.

Nielsen, B. L. H., Gøtterup, L., Jørgensen, T. S., Hansen, B. W., Hansen, L. H., Mortensen, J. and Jepsen, P. M. (2019) n-3 PUFA biosynthesis by the copepod Apocyclops royi documented using fatty acid profile analysis and gene expression analysis. Biol. Open, 8, 1-12.

Nilsson, B., Jepsen, P. M., Bucklin, A. and Hansen, B. W. (2018) Environmental stress responses and experimental handling artifacts of a model organism, the copepod Acartia tonsa (Dana). Front. Mar. Sci., 5, 156.

Pan, Y.-J., Souissi, A., Souissi, S. and Hwang, J.-S. (2016) Effects of salinity on the reproductive performance of Apocyclops royi (Copepoda, Cyclopoida). J. Exp. Mar. Biol. Ecol., 475, 108-113.

Peterson, W. (1988) Rates of egg production by the copepod Calanus marshallae in the laboratory and in the sea off Oregon, USA. Mar. Ecol. Prog. Ser., 47, 229-237.

Peterson, M. S. and Ross S. T. (1991) Dynamics of littoral fishes and decapods along a coastal river-estuarine gradient. Estuar. Coast. Shelf Sci., 33, 467-483.

Rayner, T. A., Højgaard, J. K., Hansen, B. W. and Hwang, J.-S. (2017) Density effect on the ovigerous rate of the calanoid copepod Pseudodiaptomus annandalei (Sewell 1919): implications for aquaculture. Aquac. Res., 48, 4573-4577.

Rayner, T. A., Jørgensen, N. O. G., Blanda, E., Wu, C.-H., Huang, C.-C., Mortensen, J., Hwang, J.S. and Hansen, B. W. (2015). Biochemical composition of the promising live feed tropical calanoid copepod Pseudodiaptomus annandalei (Sewell 1919) cultured in Taiwanese outdoor aquaculture ponds. Aquaculture, 441, 25-34.

Rippingale, R. J. and Hodgkin, E. P. (1977) Food availability and salinity tolerance in a brackish water copepod. Aust. J. Mar. Freshw. Res., 28, 1-7. 
593 Rivera-Ingraham, G. A. and Lignot, J. H. (2017) Osmoregulation, bioenergetics and oxidative stress 594 in coastal marine invertebrates: raising the questions for future research. J. Exp. Biol., 220, 17495951760.

596 Roddie, B. D., Leakey, R. J. G. and Berry, A.J. (1984) Salinity-temperature tolerance and 597 osmoregulation in Eurytemora affinis (Poppe) (Copepoda : Calanoida) in relation to its distribution 598 in the zooplankton of the upper reaches of the Forth estuary. J. Exp. Mar. Biol. Ecol., 79, 191-211.

599 Sabatini, M. and Kiørboe, T. (1994) Egg production, growth and development of the cyclopoid 600 copepod Oithona similis. J. Plankton Res., 16, 1329-1351.

601 Schultz, M. and Kiørboe, T. (2009) Active prey selection in two pelagic copepods feeding on 602 potentially toxic and non-toxic dinoflagellates. J. Plankton Res., 31, 553-561.

603 Su, H.-M., Cheng, S.-H., Chen, T.-I., and Su, M.-S. (2005) Culture of copepods and applications to 604 marine finfish larval rearing in Taiwan. In Copepods in Aquaculture (ed. Lee, C.-S., O'Bryen, P. J. 605 and Marcus, N. H.), pp. 183-194. Blackwell Publishing Ltd, Oxford, United Kingdom. ISBN 13: 606 978-0-8138-0066-0.

607 Svetlichny, L. and Hubareva, E. (2014) Salinity tolerance of alien copepods Acartia tonsa and 608 Oithona davisae in the Black Sea. J. Exp. Mar. Biol. Ecol., 461, 201-208.

609 Thoisen, C., Vu, M. T. T., Carron-Cabaret, T., Jepsen, P. M., Nielsen, S. L. and Hansen, B. W. 610 (2018) Small-scale experiments aimed at optimization of large-scale production of the microalga 611 Rhodomonas salina. J. Appl. Phycol., 30, 2193-2202.

612 Uye, S. and Sano, K. (1995) Seasonal reproductive biology of the small cyclopoid copepod Oithona 613 davisae in a temperate eutrophic inlet. Mar. Ecol. Prog. Ser., 118, 121-128.

614 van Someren Gréve, H., Almeda, R., Lindegren, M. and Kiørboe, T. (2017) Gender-specific feeding 615 rates in planktonic copepods with different feeding behavior. J. Plankton Res., 39, 631-644. 
617 Table 1. Overview of the experimental work. Salinity of the final food suspension is given for each 618 experiment. Prey size is the average cell size $(n=\sim 30.000)$ at start and end of the experiment (size 619 generally decreased during incubation). Prey concentrations are the minimum and maximum 620 average concentration during each incubation. All tested prey concentrations for each salinity 621 treatment can be derived from figures 2, 4 and 5. Temperature was monitored with 1-minute intervals using an ONSET HOBO ${ }^{\circledR}$ Pendant temperature logger.

623

\begin{tabular}{|c|c|c|c|c|c|c|}
\hline $\begin{array}{c}\text { Experiment } \\
\text { no. }\end{array}$ & Salinity & $\begin{array}{c}\text { Copepods } \\
\text { per 300 } \\
\mathrm{mL} \text { bottle }\end{array}$ & Prosome length & Prey size & Prey concentration & Temperature \\
\hline & $\%$ & $\mathrm{n}$ & $\mu \mathrm{m} \pm \mathrm{SD}$ & $\mu \mathrm{m} \mathrm{ESD} \pm \mathrm{SD}$ & ${\text { cells } \mathrm{mL}^{-1}}$ & ${ }^{\circ} \mathrm{C} \pm \mathrm{SD}$ \\
\hline 1 & 32 & $35-50$ & $504 \pm 43$ & $6.9 \pm 0.8$ & $0-42.388$ & $25.7 \pm 1.2$ \\
\hline 2 & 20 & $35-50$ & $501 \pm 38$ & $7.4 \pm 0.8$ & $0-38.943$ & $26.0 \pm 0.9$ \\
\hline 3 & 10 & $35-50$ & $489 \pm 38$ & n.a. & n.a. & $26.6 \pm 0.5$ \\
\hline 4 & 5 & $40-50$ & $507 \pm 28$ & $7.8 \pm 1.3$ & $0-36.576$ & $26.9 \pm 0.4$ \\
\hline 5 & $5,10,20,32$ & 50 & $495 \pm 30$ & - & 0 & $26.9 \pm 0.6$ \\
\hline
\end{tabular}


626 Table 2. Model parameters \pm SE or $95 \%$ confidence intervals (CI) for all equations fitted to the 627 observational data for mortality rate, feeding rate (ingestion and clearance rate), ovigerous rate, clutch 628 size and egg production as function of ingestion rate for Apocyclops royi at different salinities.

629

\begin{tabular}{|c|c|c|c|c|c|}
\hline & Equation & PSU & $a \pm \mathrm{SE}$ & $b \pm \mathrm{SE}$ & $\mathrm{r}^{2}$ \\
\hline \multirow{4}{*}{$\begin{array}{l}\text { Mortality rate } \\
\text { (Fig 2) }\end{array}$} & \multirow{3}{*}{$M=a+b C$} & 5 & $6.4 \pm 1.1$ & $4.9 \pm 0.0$ & 0.02 \\
\hline & & 20 & $2.4 \pm 0.6$ & $-2.0 \pm 0.0$ & 0.01 \\
\hline & & 32 & $2.1 \pm 0.6$ & $-0.0 \pm 0.0$ & 0.02 \\
\hline & & & $\beta(\mathrm{CI}, 95 \%)$ & $\alpha(\mathrm{CI}, 95 \%)$ & \\
\hline \multirow{3}{*}{$\begin{array}{l}\text { Ingestion rate } \\
\text { (Fig 4a-d) }\end{array}$} & \multirow{3}{*}{$I=\alpha \beta e^{1--\frac{a}{C}}$} & 5 & $2.32(2.14-2.49)$ & $7056(6261-7850)$ & 0.99 \\
\hline & & 20 & $1.87(1.45-2.29)$ & 7157 (4954-9360) & 0.92 \\
\hline & & 32 & $1.77(1.62-1.91)$ & $10156(8865-11446)$ & 0.99 \\
\hline \multirow{4}{*}{$\begin{array}{l}\text { Clearance rate } \\
\text { (Fig 4e-h) }\end{array}$} & \multirow{3}{*}{$F=\frac{\alpha \beta}{C} e^{1-\frac{a}{-C}}$} & 5 & $2.35(2.02-2.68)$ & $5424(4294-6553)$ & 0.67 \\
\hline & & 20 & $1.92(1.62-2.22)$ & $6448(5133-7762)$ & 0.48 \\
\hline & & 32 & $1.80(1.50-2.10)$ & 8379 (6641-10117) & 0.15 \\
\hline & & & $G_{\max }(\mathrm{CI}, 95 \%)$ & $b(\mathrm{CI}, 95 \%)$ & $\mathrm{r}^{2}$ \\
\hline \multirow{3}{*}{$\begin{array}{l}\text { Ovigerous rate } \\
\text { (Fig 5a-d) }\end{array}$} & \multirow{5}{*}{$G=G_{\max } e^{-b_{-} / C}$} & 5 & $79.5(69.0-90.0)$ & $5413(4020-6806)$ & 0.96 \\
\hline & & 20 & $89.8(79.7-100.0)$ & $12457(10422-14492)$ & 0.98 \\
\hline & & 32 & $87.0(72-3-101.7)$ & $11696(8715-14677)$ & 0.96 \\
\hline \multirow{3}{*}{$\begin{array}{l}\text { Clutch size (Fig } \\
5 \mathrm{~h})\end{array}$} & & $5,20,32$ & $19.7(19.1-20.4)$ & $527(319-733)$ & 0.2 \\
\hline & & & & & \\
\hline & & & $a \pm \mathrm{SE}$ & $b \pm \mathrm{SE}$ & $\mathrm{r}^{2}$ \\
\hline \multirow{3}{*}{$\begin{array}{l}\text { Egg prod.- } \\
\text { ingestion rate } \\
\text { (Fig 6) }\end{array}$} & \multirow{3}{*}{$S E P=a+b I$} & 5 & $3974 \pm 6394$ & $0.114 \pm 0.009$ & 0.94 \\
\hline & & 20 & $-9329 \pm 7898$ & $0.120 \pm 0.012$ & 0.86 \\
\hline & & 32 & $-4853 \pm 4795$ & $0.102 \pm 0.006$ & 0.95 \\
\hline
\end{tabular}

630

631

632 
633 Fig 1. Mortality rate during short-term $\left(\% \mathrm{~h}^{-1}\right)$ salinity acclimatisation of Apocyclops royi as 634 function of salinity. Light dots indicate replicates and black dots are the mean value. Error bars 635 indicate the standard error and different letters indicate statistically significant difference in average 636 mortality between salinities.

637 Fig 2. Food concentration dependent mortality rate of Apocyclops royi at different salinities (panel $638 \mathrm{a}-\mathrm{c})$ and average mortality $\left(\% \mathrm{~d}^{-1}\right)$ at each tested salinity (panel d) during $24 \mathrm{~h}$ incubations. Light 639 dots indicate replicates and black dots are the mean value. Discontinuous lines (panel a-c) indicate 640 the $95 \%$ confidence intervals for each fitted regression. Regression parameters are shown in Table 641 2. Error_bars (panel d) indicate the standard error and different letters indicate statistically 642 significant difference in average mortality between salinities.

643 Fig 3. Cumulative mortality rates of Apocyclops royi at different salinities during $1 \mathrm{~h}$ salinity 644 acclimatization and 24_h incubation experiments as a function of time. Dots are the mean value and 645 error bars indicate the standard error. Different letters indicate statistically significant difference in 646 average mortality between salinities.

647 Fig 4. The functional responses of Apocyclops royi feeding on Rhodomonas salina at different 648 salinity levels. Copepod ingestion rates (cells $\operatorname{cop}^{-1} \mathrm{~d}^{-1}$, panel a-c) and clearance rates $\left(\mathrm{mL} \mathrm{cop}^{-1} \mathrm{~d}^{-1}\right.$, 649 panel e-g) are presented as function of food concentration (cells $\mathrm{mL}^{-1}$ ). Black solid lines are Holling 650 type III model fits to the experimental observations. Panel $\mathrm{d}$ and $\mathrm{h}$ show model estimates of the 651 maximum ingestion rate $\left(I_{\max }\right)$ and maximum clearance rate $\left(\beta_{\max }\right)$, respectively as function of 652 salinity; error bars indicate $95 \%$ confidence intervals. All models and parameters are presented in 653 Table 2.

654 655 656 657 658 659 660

Fig 5. Food concentration dependent egg production rates of Apocyclops royi at different salinities. Female ovigerous rates ( $\%$ of ovigerous females $\mathrm{d}^{-1}$, panel a-c) and gross efficiency of egg production rates (panel e-g) are presented as function of food concentration (cells $\mathrm{mL}^{-1}$ ). Black solid lines are model fits (to the experimental observations. Panel d shows model estimates of the maximum ovigerous rate $\left(G_{\max }\right)$ and panel h food concentration dependent clutch size, respectively as function of salinity. Error bars indicate $95 \%$ confidence intervals. Models fitted to the observational data and model parameters are presented in Table 2. 
662 Fig 6. The specific egg production rate $\left(\mu \mathrm{g} \mathrm{C} \operatorname{cop}^{-1} \mathrm{~d}^{-1}\right)$ is shown as function of the specific 663 ingestion rate $\left(\mu \mathrm{g} \mathrm{C} \operatorname{cop}^{-1} \mathrm{~d}^{-1}\right)$, where the slopes of the fitted regressions equal the estimated gross 664 efficiency of egg production. Discontinuous lines indicate the $95 \%$ confidence intervals for each 665 fitted regression. Regression parameters are shown in Table 2. 


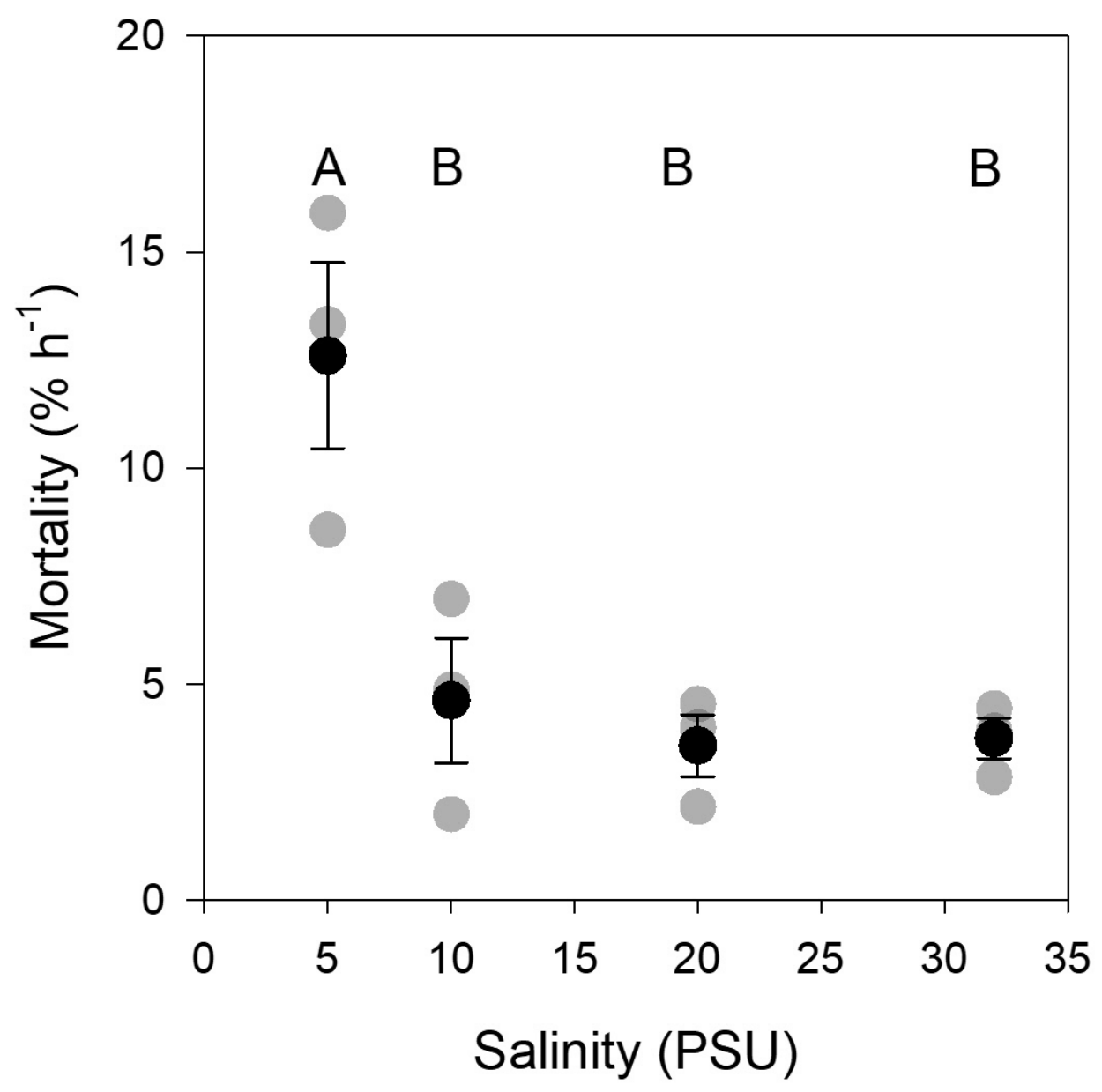

Fig 1. Mortality rate during short-term ( $\% \mathrm{~h}-1)$ salinity acclimatisation of Apocyclops royi as function of salinity. Light dots indicate replicates and black dots are the mean value. Error bars indicate the standard error and different letters indicate statistically significant difference in average mortality between salinities.

$92 \times 91 \mathrm{~mm}(300 \times 300$ DPI $)$ 

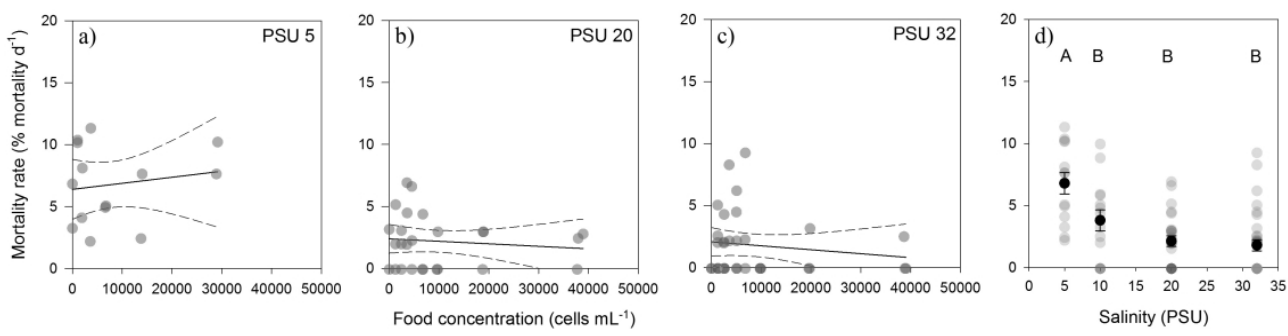

Fig 2. Food concentration dependent mortality rate of Apocyclops royi at different salinities (panel a-c) and average mortality (\% d-1) at each tested salinity (panel d) during $24 \mathrm{~h}$ incubations. Light dots indicate replicates and black dots are the mean value. Discontinuous lines (panel a-c) indicate the $95 \%$ confidence intervals for each fitted regression. Regression parameters are shown in Table 2. Errorbars (panel d) indicate the standard error and different letters indicate statistically significant difference in average mortality between salinities.

$313 \times 81 \mathrm{~mm}(300 \times 300$ DPI $)$ 


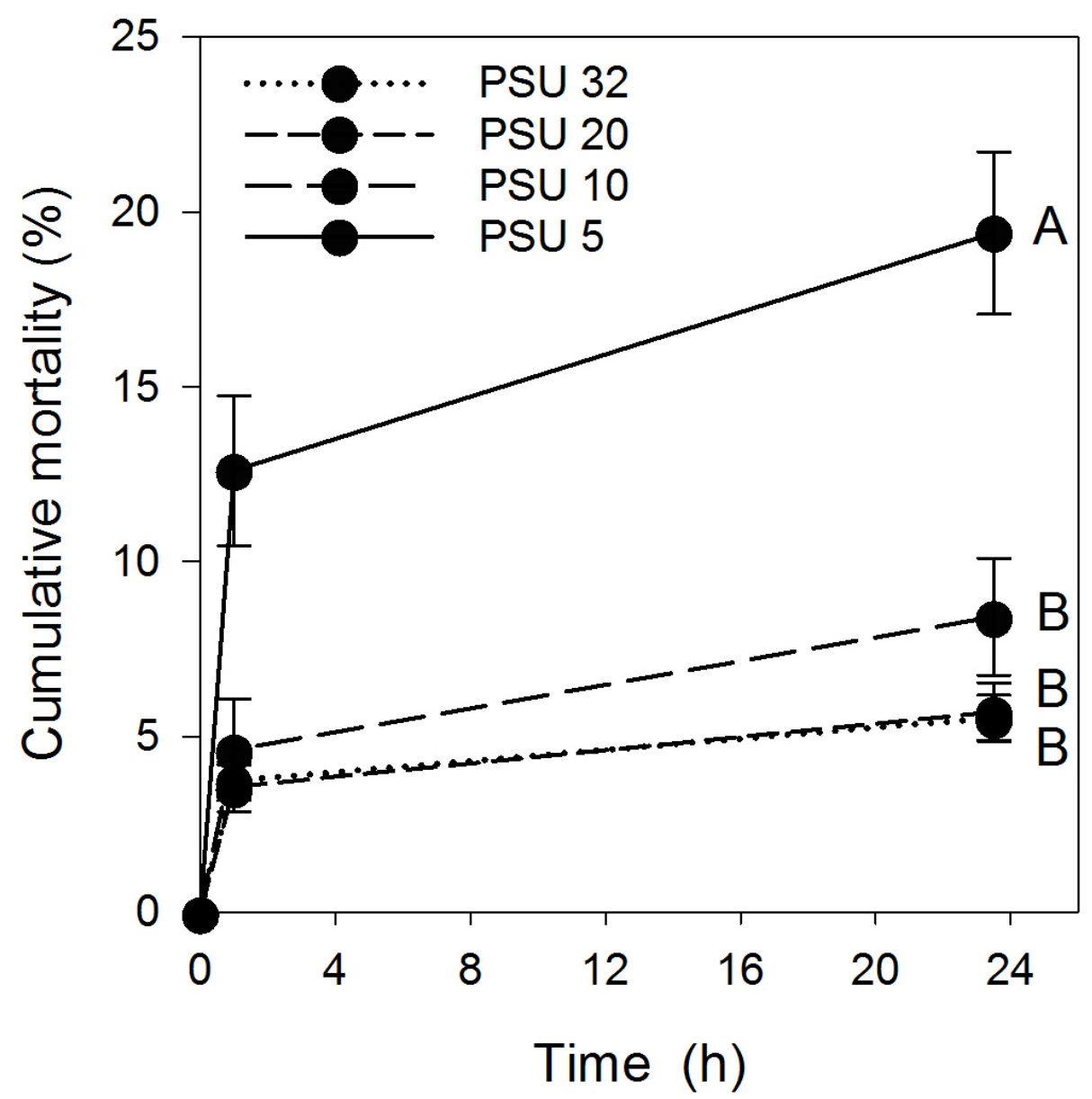

Fig 3. Cumulative mortality rates of Apocyclops royi at different salinities during $1 \mathrm{~h}$ salinity acclimatization and $24 \mathrm{~h}$ incubation experiments as a function of time. Dots are the mean value and error bars indicate the standard error. Different letters indicate statistically significant difference in average mortality between salinities.

$93 \times 92 \mathrm{~mm}(300 \times 300 \mathrm{DPI})$ 

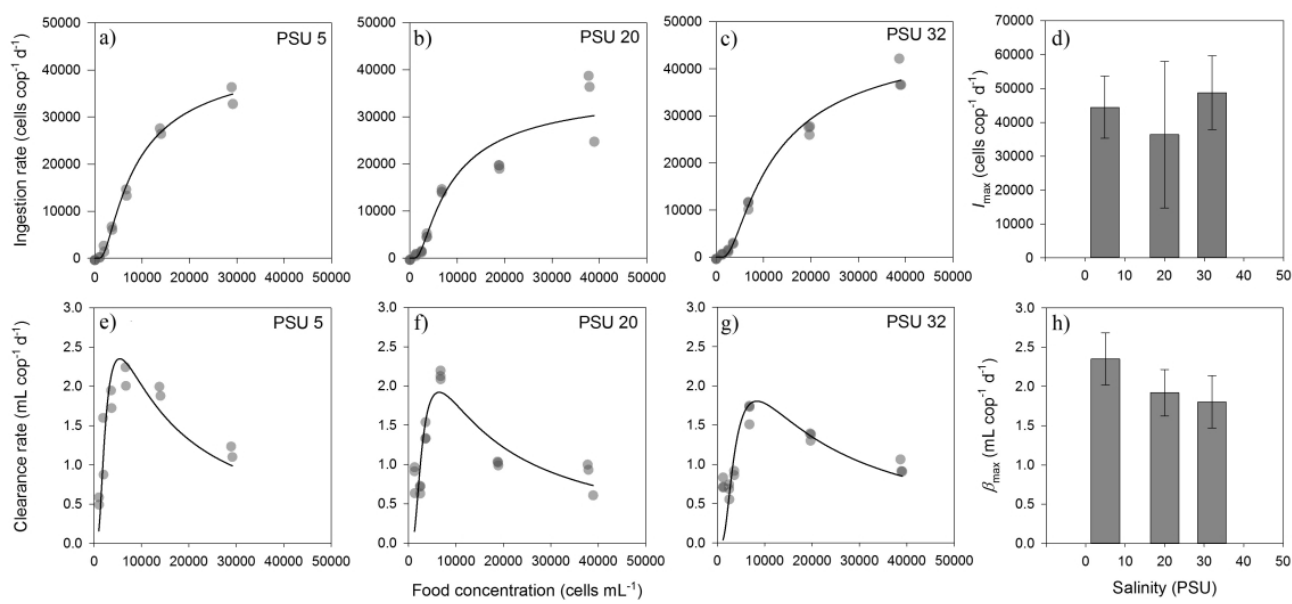

Fig 4. The functional responses of Apocyclops royi feeding on Rhodomonas salina at different salinity levels. Copepod ingestion rates (cells cop- $1 \mathrm{~d}-1$, panel a-c) and clearance rates ( $\mathrm{mL}$ cop- $1 \mathrm{~d}-1$, panel e-g) are presented as function of food concentration (cells $\mathrm{mL}-1$ ). Black solid lines are Holling type III model fits to the experimental observations. Panel $\mathrm{d}$ and $\mathrm{h}$ show model estimates of the maximum ingestion rate (Imax) and maximum clearance rate $(\beta \max )$, respectively as function of salinity; error bars indicate $95 \%$ confidence intervals. All models and parameters are presented in Table 2.

$330 \times 153 \mathrm{~mm}(300 \times 300 \mathrm{DPI})$ 

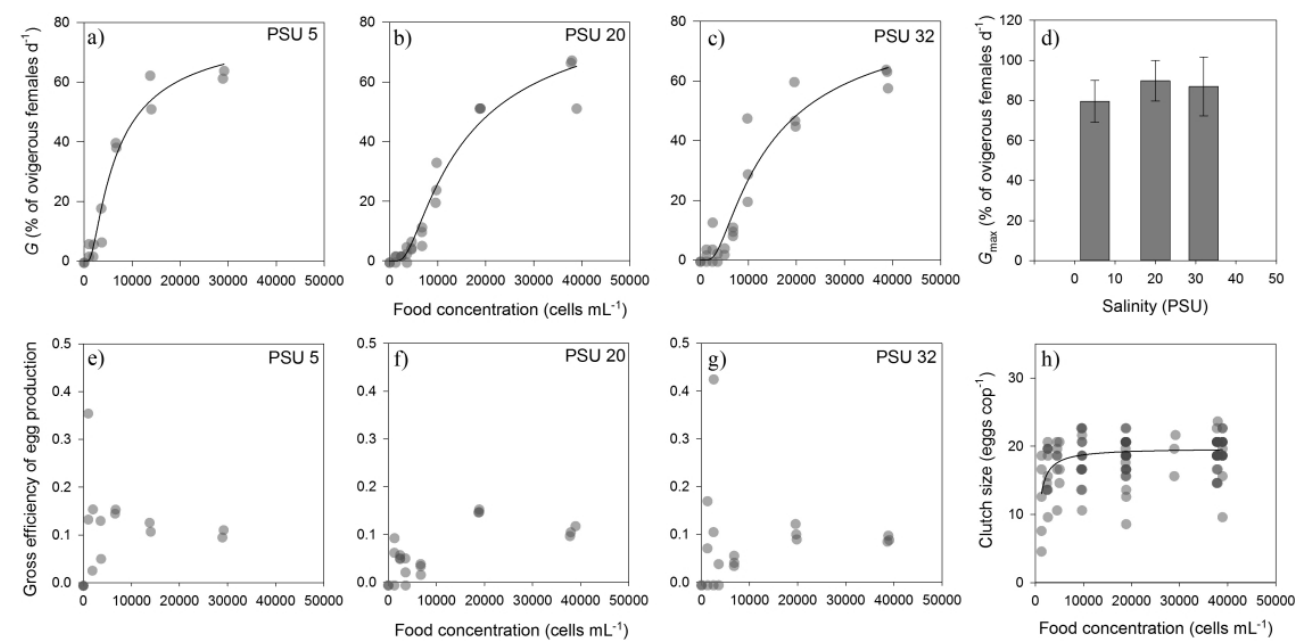

Fig 5. Food concentration dependent egg production rates of Apocyclops royi at different salinities. Female ovigerous rates (\% of ovigerous females $d-1$, panel a-c) and gross efficiency of egg production rates (panel $\mathrm{e}-\mathrm{g}$ ) are presented as function of food concentration (cells $\mathrm{mL}-1$ ). Black solid lines are model fits (to the experimental observations. Panel d shows model estimates of the maximum ovigerous rate (Gmax) and panel $\mathrm{h}$ food concentration dependent clutch size, respectively as function of salinity. Error bars indicate $95 \%$ confidence intervals. Models fitted to the observational data and model parameters are presented in Table 2.

$325 \times 164 \mathrm{~mm}(300 \times 300 \mathrm{DPI})$ 


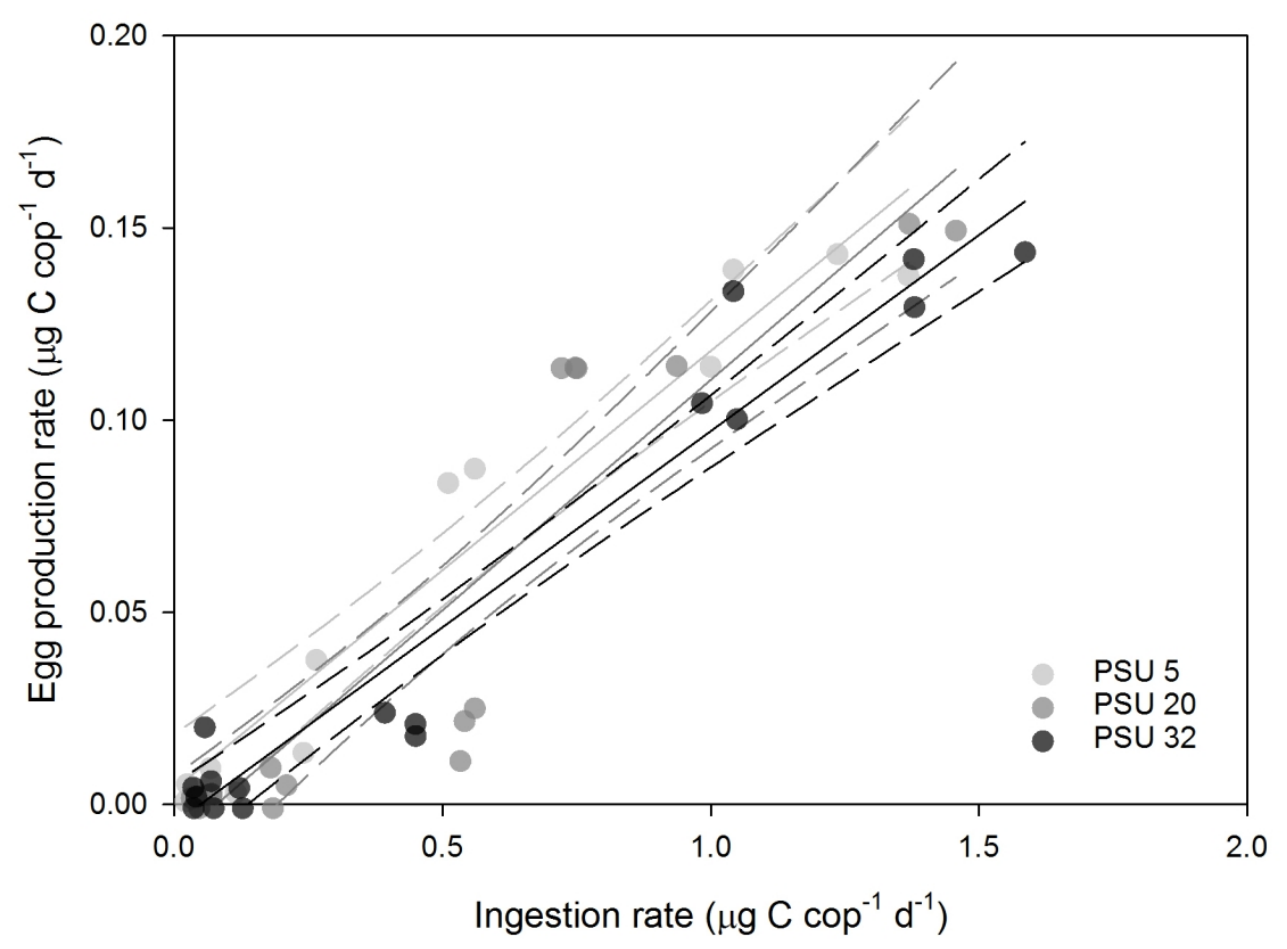

Fig 6. The specific egg production rate ( $\mu \mathrm{g} \mathrm{C} \mathrm{cop-1} \mathrm{d-1)} \mathrm{is} \mathrm{shown} \mathrm{as} \mathrm{function} \mathrm{of} \mathrm{the} \mathrm{specific} \mathrm{ingestion} \mathrm{rate}$ ( $\mu \mathrm{g} \mathrm{C} \mathrm{cop-1} \mathrm{d-1),} \mathrm{where} \mathrm{the} \mathrm{slopes} \mathrm{of} \mathrm{the} \mathrm{fitted} \mathrm{regressions} \mathrm{equal} \mathrm{the} \mathrm{estimated} \mathrm{gross} \mathrm{efficiency} \mathrm{of} \mathrm{egg}$ production. Discontinuous lines indicate the $95 \%$ confidence intervals for each fitted regression. Regression parameters are shown in Table 2.

$151 \times 119 \mathrm{~mm}(300 \times 300 \mathrm{DPI})$ 